\title{
INVESTMENT BASIS AND DEVELOPMENT TRENDS OF SMALL BUSINESS AND ENTREPRENEURSHIP IN UZBEKISTAN
}

\author{
Naim Oblomuradov \\ Doctor Of Historical Sciences Tashkent Financial Institute Social Sciences
}

\section{ABSTRACT}

The article describes the investment basis, historical factors and development trends in the development of small business and entrepreneurship in the years of independence of Uzbekistan. It describes the state policy to increase the attractiveness of the investment climate, important factors, conditions and some problems in attracting foreign investment. The article notes that the integration of the industry into the world economic system has allowed Uzbekistan to improve the domestic socio-economic environment, ways to actively attract investment and use it wisely by further encouraging entrepreneurs.

KEYWORDS: - Small business, entrepreneurship, historical factor, investment, investor, credit, enterprise, property, privatization, market, bank, capital, industry, import, joint venture.

\section{INTRODUCTION}

The socio-economic development of any country, the growth of incomes, the improvement of living standards depend on the volume and composition of foreign investment in various sectors of the national economy. If we look at the new historical period of Uzbekistan (19912020), we can see that a number of measures have been taken to increase the attractiveness of the investment climate in the development of small business and private entrepreneurship in the country. In accordance with the Action Strategy for the five priority areas of development of the Republic of Uzbekistan for 2017-2021, significant work has been done in recent years to deepen structural changes in the state program, increase its competitiveness through modernization and diversification of key sectors of the national economy. Uzbekistan's consistent approach to the denationalization and privatization of property, the development of entrepreneurship and business is creating real conditions for intensifying the process of attracting foreign investment to the country's economy.

\section{THE MAIN RESULTS AND FINDINGS}

In the early years of Uzbekistan's independence, a number of normative and legal acts were adopted on the development of small business and private entrepreneurship and attracting investment in them. Among them was the adoption of the Law "On Foreign Investment in the Republic of Uzbekistan" on June 14, 1991, which defined the legal, organizational aspects and procedures for the introduction of foreign investment in the country. This law was adopted 
CURRENT RESEARCH JOURNAL OF HISTORY 2(6): 01-06, June 2021

DOI: https://doi.org/10.37547/history-crjh-02-06-01

ISSN 2767-472X

(C)2021 Master Journals

\section{Crossref do) 81 Google}

Accepted 05 ${ }^{\text {th }}$ June, 2021 \& Published 10 thJune, 2021

in 1998 on a new basis [1. 1998 №7. p 12].

According to historical analysis, before independence in 1990 there was almost no foreign investment in the investment portfolio of the former Soviet Union, in 1994 there were 586 joint ventures in Uzbekistan, 560 were foreign investments, in 1995 1,000 joint ventures which were about 1 billion soums. About 10,000 entrepreneurs, mostly farmers, have been supported by money from privatization. Researchers note that, for example, in 1997, total investment was $\$ 271.6$ billion soums, of which 217.6 bln. UZS (78\%) national investment, 54 billion soums (22\%) was foreign investment. $2.3 \%$ of investments are directed to production, which specializes primarily in the introduction of new technologies, the production of marketable products [2. 2000, p.64-65].

In 1994-1996, the second phase of small business and private entrepreneurship and foreign investment, the government took important measures related to small-scale privatization. As a result, in 1995, Uzbekistan was one of the first CIS countries to achieve positive results in terms of economic growth. The favorable business environment created for foreign investors, a wide range of legal guarantees and benefits, measures to encourage enterprises with foreign investment have allowed to radically increase the inflow of direct investment into the economy of our country.

If we look at the historical figures, in the first years of independence, due to the conditions created for foreign investors in the country, there have been many positive developments in this area. During this period, Uzbekistan has signed investment agreements with Germany, Turkey, Egypt, Indonesia, Pakistan, Finland, the United States and France to finance business. [3. p 17]. In recent years, this figure has risen steadily. According to the data, in 1997 the share of foreign investment in the republic was $19.9 \%$ of the total disbursed capital, and in $2000-21.7 \%$. This confirms the growth of only $2 \%$ in three years.

The bulk of foreign capital came from joint ventures. For example, as of January 1, 2001, there were 1,796 joint ventures with entrepreneurs from 70 countries in Uzbekistan. In particular, joint ventures with large firms from the United States, Germany, South Korea, Russia and other countries have been successful, Akhmediyeva writes. For example, in 1997, total investments amounted to 271.6 billion UZS, of which $78 \%$ is national investment, 54 billion. soums, $22 \%$ of which was foreign investment. That is, two-thirds of the investment was directed to production, which was primarily directed to the introduction of new technologies, the production of marketable products.

But at the same time, there were some problems in the industry. One of them was to register investors and create the necessary opportunities for them. In fact, the law provides for the registration of investors and the creation of opportunities for their activities in the absence of violations in the activities of investors. According to the law, foreign legal entities have the right to own property in the territory of the Republic of Uzbekistan, which is not prohibited by the legislation of the Republic of Uzbekistan and is necessary for economic and other activities. The property of foreign legal entities is protected by the state. The increase of property and its free transfer to other countries is guaranteed by law [4. p. 37-38].

Among such problems are the statistics for the years of independence, including the fact that until 2002, no enterprises with foreign investment were established in 31 districts of the country. If at the beginning of 2000 there were 143.5 thousand enterprises, in 2002 there were 240 thousand small and medium enterprises in the country. From these, 85,000 are farms. The 
CURRENT RESEARCH JOURNAL OF HISTORY 2(6): 01-06, June 2021

DOI: https://doi.org/10.37547/history-crjh-02-06-01

ISSN 2767-472X

(C)2021 Master Journals

\section{Crossref do) 81 Google}

Accepted 05 ${ }^{\text {th }}$ June, 2021 \& Published 10 ${ }^{\text {th June, }} 2021$

private sector employs 30 percent of the population. Some researchers estimate that private companies account for 35 percent of GDP. [5. p 78.]. Thus, due to the conditions created for foreign investors in the country, there have been many positive developments in this area. During this period, Uzbekistan has signed investment agreements with Germany, Turkey, Egypt, Indonesia, Pakistan, Finland, the United States and France to finance business.

For example, in 2008 \$1billion 700million Foreign investment was disbursed, which is $46 \%$ more than in 2007. Most importantly, $74 \%$ of foreign investment was direct investment. About $54 \%$ of all investments were made by enterprises and the population. This once again confirms the correctness of the tax policy pursued in our country to reduce the tax burden and encourage investment activity of businesses.

Of course, if we take into account the attraction of foreign investment in the business sector in the regions, the situation becomes even clearer. According to research, the situation with their involvement in different regions of the country varies due to certain disproportions and gradations. For example, in Andijan region, the share of foreign investment in entrepreneurship increased by $3.3 \%$ in 2000 compared to previous periods, by 23\% in 2011 (almost 7\%), in Bukhara region by $9.0 \%$ to $69.9 \%$, respectively, in Kashkadarya region it increased from $0.1 \%$ to $22 \%$. These figures remain in Jizzakh, Khorezm and Surkhandarya regions at 5.3-6.8\%. Even if some archival data is analyzed in this regard, it is possible to see a closer look at the above facts. In other words, most of the joint ventures were in Tashkent and Tashkent region, Samarkand and Andijan regions. There are two reasons for this:

First, the differences between business entities established in the regions at the expense of foreign investment are that these areas are not considered a priority in those spheres;
Second, in some of these regions, the investment climate is imperfect and insufficient conditions are created for foreign investors [6. p 338].

However, it is natural that economic relations with the country with which the investment cooperation is positive will be at the level of demand. Therefore, Uzbekistan has established cooperation with countries near and far abroad in this area. Historically, the share of CIS countries in Uzbekistan's foreign trade has been lower than in foreign countries. In particular, in 2008 the share of CIS countries in Uzbekistan's foreign trade amounted to $38.7 \%$. The figure was $34.7 \%$ for export transactions and $42.7 \%$ for import transactions [7. p 61].

Russia (49.5\%) and Kazakhstan (11.5\%) are the leaders in foreign economic relations among the CIS member states. At that time, our country's foreign economic relations with the rest of the CIS were very low. In 2008, the Russian Federation led Uzbekistan's import operations with the CIS countries, accounting for a quarter of total imports and amounted to 1,863 million US dollars. The largest share of imports (13.8\%) fell to China and the Republic of Korea (12.9\%). Overall, countries with more than $5 \%$ of imports accounted for Ukraine (8.3\%), Kazakhstan (6.0\%), and Germany (5.3\%) [8. p 61].

In recent historical periods, the conditions created for investors have also begun to change for the better. For example, in 2015, according to the World Bank's Doing Business report, Uzbekistan was included in the top ten reformers in 2014 and 2015, the country that created the most favorable conditions for doing business. According to World Bank experts, it takes relatively little time to set up a business in Uzbekistan. In this regard, for example, 1.5 times less than in Japan, 1.6 times less than in Germany, twice as much as in Greece and Israel, 2.2 times less than in Spain, and 4.8 times less 
CURRENT RESEARCH JOURNAL OF HISTORY 2(6): 01-06, June 2021

DOI: https://doi.org/10.37547/history-crjh-02-06-01

ISSN 2767-472X

(C)2021 Master Journals

\section{Crossref do) 81 Google}

Accepted 05 ${ }^{\text {th }}$ June, 2021 \& Published 10 thJune, 2021

than in China. In addition, the level of tax burden on small business in our country is much lower than in the United States, Canada, Germany, Austria, France, Italy, Spain, Greece, Japan, China, Belarus and a number of other countries [9. p. 2].

According to the World Bank's economic rating, Uzbekistan ranks 63rd out of 190 countries. According to the World Economic Forum, Uzbekistan is one of the five fastest growing countries in the world in 2014 and 2015 and in 2016-2017. In 2017, it rose to 74th place in the world ranking of ease of doing business, 11th place in terms of business registration, 27th place in terms of access to electricity, lending ranked 55th and 73rd in terms of private property registration [10.№1]. High rates of economic growth have ensured a relatively balanced distribution of income among the population.

One of the important directions in attracting foreign investment to the national economy in Uzbekistan is the formation of special economic zones in the country. Navoi, Jizzakh, Angren, Gijduvan, Kokand, Urgut, Hazarasp free economic zones have been established in the country and are currently operating effectively. As of JanuarySeptember 2018, the volume of foreign investments and loans in fixed assets amounted to 17770.6 billion soums, the share of foreign investments and loans in total investments amounted to $25.0 \%$, directly The share of foreign investments and loans amounted to 7336.6 billion soums, the share of foreign direct investment and loans in the total volume of foreign investments and loans amounted to $41.3 \%$. The above analysis shows that in JanuarySeptember 2018, the amount of foreign investment increased by almost 2.5 times compared to 2010 due to the conditions created for foreign investors, in particular, the timely formation of the regulatory framework. [11. p 53].
If we turn to the statistics, in 2001-2017, the number of small businesses and private entrepreneurship in the country increased from 99 thousand to 229 thousand, in the first half of 2018 the number of such enterprises amounted to 247.7 thousand. Accordingly, as of January 1, 2016, the number of small businesses with foreign capital reached 4,564. Only in 2015, 386 enterprises based on foreign capital were established in the country. As of January 1, 2019, the number of enterprises with foreign capital operating in the country amounted to 7,560. This is explained by the fact that compared to 2018, the number of enterprises increased by 2043. From the existing enterprises, 4,006 were small joint ventures and 3,554 were foreign enterprises [12. p 21].

In his Address to the Oliy Majlis on the most important priorities for 2019, President Mirziyoyev focused on investment and said that which state has active investment politics, it has achieved sustainable growth of its economy. That is why investment is the driver of the economy, in Uzbek, the heart of the economy. " In his address, the President noted that despite the significant work being done to improve the business environment in the country, in some respects we still rank low among the countries of the world. In particular, according to the World Bank's Doing Business ranking, our country ranks 134th in construction. This indicates that there are many problems in the industry. For example, there are 17 permit procedures in the construction industry, which take an average of 246 days to obtain, he said.

In terms of regions, the majority of small, medium and large enterprises based on private entrepreneurship with foreign capital are in Tashkent city with 4728 (total share 62.5\%), Tashkent region 851 (11.3\%) and Samarkand region 396 body (5.2\%). The lowest number of 
CURRENT RESEARCH JOURNAL OF HISTORY 2(6): 01-06, June 2021

DOI: https://doi.org/10.37547/history-crjh-02-06-01

ISSN 2767-472X

(C)2021 Master Journals

\section{Crossref do) 81 Google}

Accepted 05 ${ }^{\text {th }}$ June, 2021 \& Published 10 thJune, 2021

enterprises with foreign capital was in Khorezm region (0.9\%), Kashkadarya - 85 (1.1\%), Navoi region - 109 (1.4\%) and the Republic of Karakalpakstan - 121 (1.6\%) [13 . December 29, 2018].

Studies have shown that in some areas with low performance, it is necessary to work with foreign partners and further develop the work that needs to be done to attract investment. If we consider small enterprises with foreign capital in terms of economic activity, the largest number is 2995 (39.6\%) in industry, 1668 (22.0\%) in trade and $1225(16.2 \%)$ in other activities. did The lowest rates were in health and social services (97\%), information and communication - 209 (2.8\%), transportation and storage - 214 (2.8\%). and 339 (4.5 percent) in fisheries, 325 (4.3 percent) in accommodation and catering services, and 488 (6.5 percent) in construction [14. 2019. 01. №1. ].

\section{Conclusion}

In conclusion, it can be said that the measures taken in Uzbekistan to attract foreign investment in business and entrepreneurship, technical and technological modernization of enterprises in the business sector, increase the number and quality of products and increase competitiveness will further develop the country's economy. The following factors are important for the active attraction of foreign investment in Uzbekistan today:

First, it confirmed that the active domestic and foreign policy, favorable conditions for foreign investors, the preservation of peace and tranquility in the country, the positive macroeconomic and microeconomic indicators of the country are the main factors in actively attracting foreign investment;

Second, Uzbekistan is establishing equal partnerships with foreign investors on the basis of economic relations, especially with developed countries that have their own prestige in the world. Indeed, the investments have shown that the country's economy is supported by a wide range of opportunities for its development;

Third, world experience shows that countries that are transitioning to a market economy cannot successfully integrate into the world economic community without creating a favorable investment climate and actively attracting foreign investment to the national economy.

Fourth, Uzbekistan's consistent path of denationalization and privatization, entrepreneurship and business development has confirmed that it creates real conditions for intensifying the process of attracting foreign investment to the country's economy.

\section{REFERENCES}

1. Миренский Б. Новое инвестиционное законодательство Республики Узбекистан.// Ўзбекистонда ижтимоий фанлар.Т., 1998 №7. С 12.

2. Olmasov A, Vakhobov A. Restructuring the economic system is a unique way to transition to a market economy. // The first pages of the history of independent Uzbekistan. "East". T., 2000, 64-65 p.

3. Uz MA Fund-M-20, List 1, Volume 10, Page 148.

4. Strategy of Uzbekistan is a socio-analytical journal of the Center for Development Strategy. 2018 № Issue 2.

5. Zaynutdinov Sh.N, Karmisheva Sh.K. Investment management. T. 2007. Pages 37- 38 .

6. Egamberdiyev E, Khojakulov H. Small business and entrepreneurship. T., 1999 78p.

7. Надырханов У. Региональные аспекты 
CURRENT RESEARCH JOURNAL OF HISTORY 2(6): 01-06, June 2021

DOI: https://doi.org/10.37547/history-crjh-02-06-01

ISSN 2767-472X

(C)2021 Master Journals

Crossref dof 81 Google

Accepted 05 ${ }^{\text {th }}$ June, 2021 \& Published 10th June, 2021

привлечеиния иностранных

инвестиций в экономику. // Стратегия

дальнейшего повышения

конкурентоспособности национальной

экономики. Т.. 2012. C-338.

8. Saparov B. Improving Uzbekistan's foreign trade relations in the context of the global economic crisis. // Materials of the Republican scientific-theoretical conference. T., 2009. Page 61.

9. Экономическое развитие Республики Узбекистан за годы независимости. Т., 2016. C 2.

10. Узбекистан в оценках и соспоставлениях // Экономическое обозрение. Т., 2018. №1.

11. A popular scientific manual dedicated to the study and popularization of the Address of the President of the Republic of Uzbekistan Shavkat Mirziyoyev to the Oliy Majlis. T., 2019. p.53.

12. Rashidova F.Sh. Current investments in the formation and development of small business and private entrepreneurship in Uzbekistan.//Association of the dissertation for the degree of Doctor of Philosophy in History. Tashkent-2019. Page 21.

13. Address of the President of the Republic of Uzbekistan Shavkat Mirziyoyev to the Oliy Majlis. "People's word". T., December 29, 2018

14. An important stage in international relations.// People's speech. 2019. 01. №1. 